University of South Florida

DIGITAL COMMONS

@ UNIVERSITY OF SOUTH FLORIDA
Digital Commons @ University of

South Florida

$1-1-2002$

\title{
Florida Public Transit System Anti-Terrorism Resource Guide
}

CUTR

Follow this and additional works at: https://digitalcommons.usf.edu/cutr_nctr

\section{Scholar Commons Citation}

CUTR, "Florida Public Transit System Anti-Terrorism Resource Guide" (2002). Research Reports. 221.

https://digitalcommons.usf.edu/cutr_nctr/221

This Technical Report is brought to you for free and open access by the National Center for Transit Research (NCTR) Archive (2000-2020) at Digital Commons @ University of South Florida. It has been accepted for inclusion in Research Reports by an authorized administrator of Digital Commons @ University of South Florida. For more information, please contact digitalcommons@usf.edu. 


\section{Florida Public Transportation Anti-Terrorism Resource Guide}
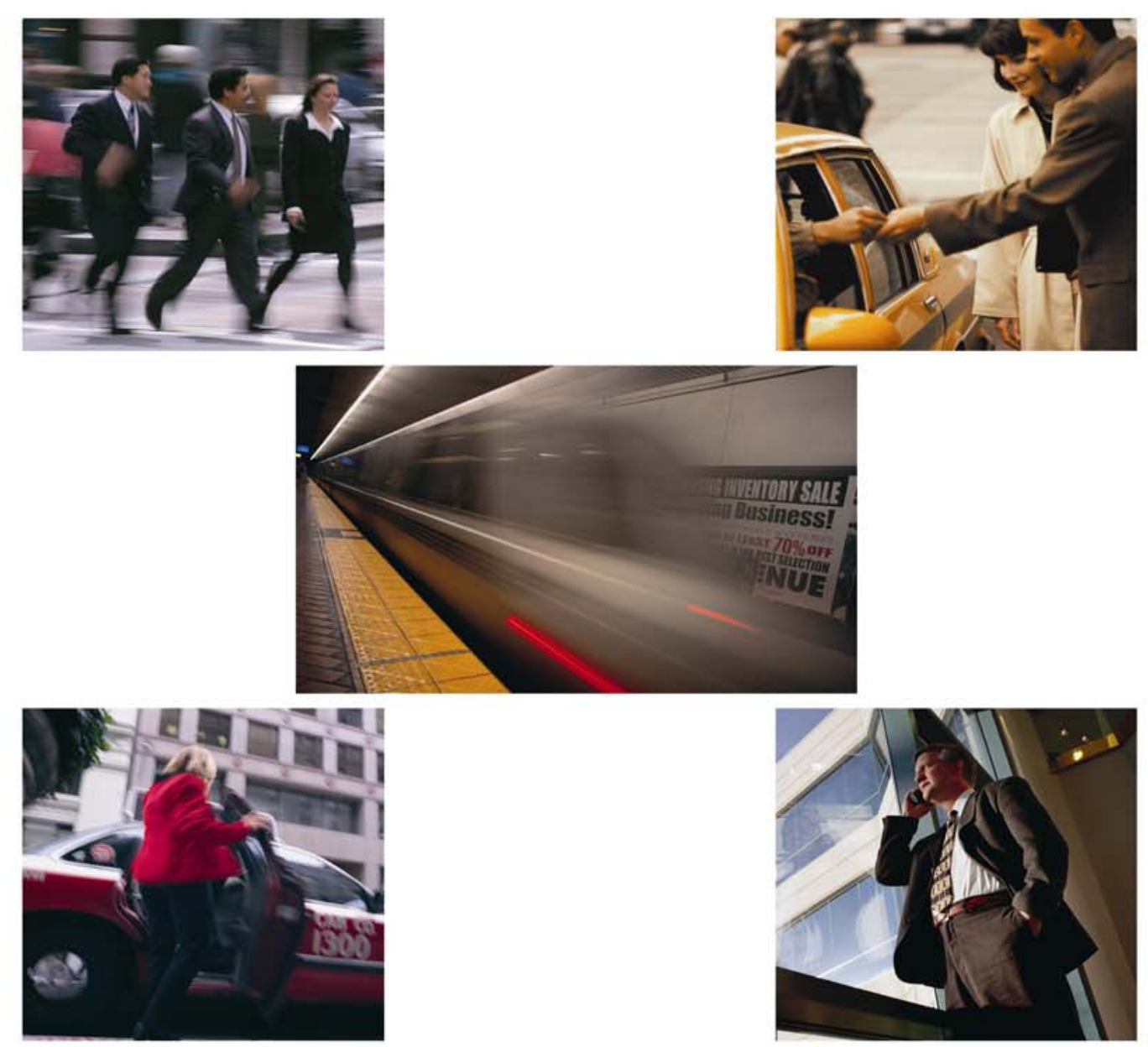

Prepared By:

National Center for Transit Research (NCTR)

Center for Urban Transportation Research

University of South Florida

College of Engineering

4202 East Fowler Avenue, CUT 100

Tampa, Florida 33620

(813) 974-3120, voice

(813) 974-5168, fax

www.cutr.eng.usf.edu

Sponsored By:

Florida Department of Transportation Technical Assistance Training Program 



\section{Florida Public Transit System Anti-Terrorism Resource Guide}

\section{INTRODUCTION}

The Center for Urban Transportation (CUTR) at the University of South Florida (USF) assembled this guide to provide public transit agencies in Florida with information on current resources available to assist them with improving system security and guard against potential terrorist acts. Specifically, the document contains information on:

- Federal and the State of Florida anti-terrorism resources for public transit agencies;

- Resource documents to assist transit agencies in developing or enhancing security plans and procedures; and

- Training programs and seminars on transit security and anti-terrorism.

The Florida Department of Transportation Technical Assistance Training Program funded this resource guide. For more information or assistance with locating information in the guide, please e-mail Lisa Staes at staes@cutr.eng.usf.edu or Patricia Turner at turner@cutr.eng.usf.edu or telephone at (813) 974-3120.

\section{FEDERAL RESOURCES}

In the wake of the September 11, 2001 terrorist attacks, the U.S. Congress unanimously approved September 14 and President Bush signed into law September 18 an emergency supplemental appropriations bill for Fiscal Year 2001 that will provide $\$ 40$ billion for disaster and recovery assistance and anti-terrorism initiatives.

The disaster response package will make funds available to federal, state, and local preparedness for mitigating and responding to the attacks; to support counter, investigate, or prosecute domestic or international terrorism; to provide increased transportation security; to repair public facilities and transportation systems damaged by the attacks; and to support national security. (Source: "Federal Emergency Funding Approved in Response to Terrorist Attacks", Passenger Transport, Vol. 59, No 38, September 24, 2001, p. 1).

During an October 4, 2001 hearing on transit safety, leaders of the U.S. Senate Banking, Housing, and Urban Affairs Committee pledged support in boosting public transportation agency safety and security. Subcommittee ranking member Sen. Wayne Allard (R-Colo) said that as aircraft become more difficult to attack, public transportation facilities, which carry large numbers of people along predictable routes, could become the next target. Members had a general consensus that transit should become a permanent key component in evacuation plans of cities nationwide.

Federal Transit Administrator Jennifer L. Dorn outlined several important Federal Transit Administration (FTA) activities underway to assist transit agency preparedness and emergency response. These include the distribution of security toolkits containing resources designed to improve transit security; assistance for agencies in conducting vulnerability assessments and refining emergency response plans; and workshops on these issues. Moreover, the agency plans to expand their emergency response training. (Source: "Senate Panel Pledges Support to Enhance Transit Safety, Security”, Passenger Transport, Vol. 59, No. 41, October 15, 2001).

\section{Federal Transit Administration (FTA)}

The FTA maintains a web site that addresses transit safety and security issues. (See the FTA Safety and Security web site at http://transit-safety.volpe.dot.gov.) Materials created by the Office of Safety and Security can help transit agencies develop their security plans and establish security procedures. The following excerpts are from the web site.

\section{Safety and Security Program}

The Federal Transit Administration's Safety and Security Program goal is to promote public health and safety by working toward the elimination of transit-related deaths, injuries, property damage and the improvement of personal security and property protection. This is accomplished through the promotion of transit safety and security in the transit community. FTA encourages transit systems to collect and disseminate data on safety and security issues, 
identify and implement best practices, and develop and implement comprehensive system safety and security program plans covering passengers, transit agency personnel, vehicles, and facilities.

FTA participates in a number of intermodal U.S. Department of Transportation (USDOT) efforts to develop safety and security strategies that promote national transportation interests. In partnership with the transit industry, national security agencies, and international transportation organizations, FTA continues to test and evaluate advanced technologies (including chemical and biological detection systems) to reduce transit crime and counter terrorism targeted at transit patrons, employees and facilities.

The main focus areas of the Safety and Security Program are Railroad Safety, Information Systems Security, Crime Prevention and Anti-Terrorism and Intelligent Vehicle Initiative.

\section{Crime Prevention and Anti-Terrorism Program}

(http://www.fta.dot.gov/research/safe/crimeprev/crimeprev.htm)

Through this program, the Federal Transit Administration will demonstrate innovative security technologies, system design, and rail and bus vehicle security enhancements.

Consistent with the recommendations of the President's Commission on Critical Infrastructure Protection, the FTA will identify possible key terrorist targets in transit and evaluate the economic consequences of disruption to transit service in those markets. Core systems that may be vulnerable to terrorist acts will need to develop fail-safe interventions.

The FTA will explore other options to improve transit security. Specific actions will include accessing transit vulnerabilities, examining current transit systems' terrorism prevention programs, identifying technologies, developing procedures, and providing appropriate recommendations to enhance transit security. Of particular importance will be a risk assessment of the range of transportation services at airports served by rapid transit lines. The FTA will also develop a computer model for application in field operations that simulates the transit environment, including medical triage, contingency transit, emergency evacuation routes, and vulnerable locations points, which will aid security personnel in responding to catastrophic transit events.

Selected activities under this program include:

Development of an advanced multi-sensor system that incorporates full data fusion: The goal of this program will be to tie together ten or fewer Urban Chemical Release Detector (UCRD) multi-sensor detector instruments that will be installed in a variety of locations within a subway station. The use of this system will result in a significant reduction in the false alarm rate without a concurrent degradation of high probability of detection. The proposed fully integrated system will use a flexible modular architecture so that other instruments and detector types can be included, such as meteorological, fire, smoke, and biological agents. The design focus will be on ease of system deployment in any location without introducing interference with the existing system infrastructure.

Detailed validation of the Subway Environmental Simulation Chemical and Biological (SESCB) numerical modeling code: A fully validated code can be used to confidently predict the possibility of identifying and quantifying the threat created from the release of a variety of chemical and biological agents. Sensor instruments as described above can be used to validate the code predictions in a subway station during simulated chemical and biological releases. This effort will also employ the SESCB model to access and define consequence assessment and crisis management tools.

Security Survey - Public Perception: Collection and analysis of data on safety and security concerns provides FTA with a basis for identifying key issues. The security survey will: (1) determine concerns of citizens regarding public transit in and around their neighborhoods and (2) assess and evaluate these concerns in conjunction with and relation to transit designs for livable communities. This information will be invaluable for more effectively meeting transportation needs of diverse communities throughout the nation.

Safety/No Tolerance Conference: At transit agencies where the "no tolerance" policy has been in effect, the record indicates that crime is considerably lower than on those systems where minor infractions are tolerated. This conference would explore enforcement of a "no tolerance" policy to discourage minor infractions in public transit which impact the level of criminal activity in transit as well as the public perception of the security of the transit system. The comfort level of transit riders is increased with the awareness that a "no tolerance" policy for minor infractions is imposed and seriously enforced. 
The FTA also funds a number of transit safety and security training programs through the Transportation Safety Institute. The listing of courses and seminars in transit security and safety can be accessed online at www.tsi.dot.gov, or by contacting Jim Lopez, manager of TSI's Transit Safety and Security Division, at telephone (405) 954-3682. (Courses are detailed in the training resource section of this guide.)

\section{American Public Transportation Association (APTA)}

APTA has a number of safety and security resources to assist transit systems' efforts to enhance safety and security. (See website at http://apta.com/). Agencies that have not developed system safety program plans or security plans can obtain information on APTA's system safety programs for bus, rail, and commuter rail operations through APTA's Safety and Security Section at telephone (202) 496-4879, or by e-mail to ghull@apta.com.

APTA also has a transit security committee called the Committee on Public Safety that provides a forum for information sharing and interagency support. Persons interested in participating in the committee can contact APTA's Safety and Security Section at telephone (202) 496-4879.

To be responsive to Congress and the Administration, APTA staff has started preliminary work to identify areas of need for funding support in public transportation safety and security. Initial discussions to identify capital items, operations items, and research and development needs in transit safety and security are underway.

APTA also produces the Passenger Transport, a weekly newspaper of the public transportation industry. The paper's resources on terrorism and public transportation include:

Passenger Transport, Volume 59, No 37, September 17, 2001. This edition contains an article on public transit's reactions to terrorist attacks and contains a list of resources regarding the effect of terrorist attacks on public transportation systems. http://www.apta.com/news/pt/0917-response.htm

Passenger Transport, Volume 59, No 38, September 24, 2001. This edition contains articles on federal emergency funding in response to terrorist attacks, public transit's response in the aftermath of the terrorist attacks, and transit security programs and resources.

Passenger Transport, Volume 59, No. 41, October 15, 2001. This edition contains an article on the U.S. Senate Banking, Housing, and Urban Affairs Committee pledge to support enhanced transit safety and security.

American Public Transportation Association Information Center Briefing, September 2001: Terrorism and Public Transportation. This special briefing was compiled in response to the heinous terrorist attacks on New York City and Washington D.C. on September 11, 2001. The briefing identifies documents available on the Internet that may be of use to public transportation systems preparing to defend against further acts of terrorism. http://www.apta.com/info/briefings/briefing_4_special.html

The APTA Information Center has compiled 13 complete Emergency Preparedness Plans from small and large transit agencies onto a CD-ROM. Copies are available free to APTA members, and for sale for $\$ 25$ to nonmembers. Persons can order a copy of the CD-ROM by sending e-mail to info@apta.com, including their postal address in the e-mail message.

APTA has established a safety and security "list-serv" for members on its web site www.apta.com to share information or discuss concerns on how the terrorist attacks have affected their transit systems or business. 


\section{Amalgamated Transit Union (ATU)}

The following was posted on the ATU web site (http://atu.org).

\section{Recent Assaults on Mass Transportation in the US}

- November 4, 2001: A passenger tried to grab the wheel of a Greyhound bus, causing the vehicle to turn on its side and injuring more than 30 people. The bus, carrying 38 people, was about 40 miles south of Phoenix, when a man approached the driver. During the scuffle, the bus drove off the pavement, then back onto the roadway before turning on its side. Thirty three-people were taken to hospitals, none with life-threatening injuries. (Source: CNN.com, November 4, 2001).

- October 17, 2001: A man tried but failed to commandeer a Greyhound bus bound for Nashville, Tennessee. The driver of the bus successfully stopped the vehicle on the side of the road after passengers wrestled the unidentified hijacker away from the driver. The bus was traveling from Portland, Oregon, to Nashville, and had just left Salt Lake City. (Source: CNN.com, October 18, 2001)

- Oct 16, 2001: Passengers subdued a disturbed man who attempted to take control of a Greyhound bus near Oklahoma City. (Source: The Clinton Courier, October 16, 2001)

- October 3, 2001: Six people were killed in a disturbance on a Greyhound bus near Manchester, Tenn. A man described as "deranged" slit the throat of the driver on a trip from Chicago to Orlando, Fla. The assailant died in the crash but the bus driver survived.

- $\quad$ August 3, 2001: A Greyhound bus passenger opened fire on a bus arriving at a midtown Manhattan terminal, wounding four other passengers. (Source: Associated Press, August 4, 2001)

- July 7, 2001: A man slammed his car into the back of a Metro Transit bus in Washington, D.C., then boarded the bus and attacked the driver, throwing him off the vehicle. The attacker tried to commandeer the bus but fled when he heard sirens approaching. (Source: The Washington Post, July 9, 2001)

- $\quad$ May 2, 2001: A shooting suspect hijacked a city bus in Los Angeles and held a gun to the driver's head as police chased the bus through downtown until it crashed into a minivan, killing the minivan driver and injuring seven others. (Source: The New York Times, May 2, 2001)

- April 21, 2001: A passenger punched a Metro Transit bus driver as he was exiting the bus in Minneapolis after the bus driver asked the passenger and his friend to move their legs because they were blocking the rear exit. (Source: WCCO 4 News, April 30, 2001)

- March 24, 2001: A New York transit bus operator was punched in the face numerous times after five men stopped the bus he was driving by standing in front of it and then pried the front doors open. (Source: New York Metropolitan Transportation Authority)

- March 6, 2001: A SEPTA bus driver was beaten by a group of passengers who boarded his bus in Philadelphia, Pennsylvania. (Source: The Inquirer, March 7, 2001)

- February 4, 2001: A woman was sexually assaulted in the bathroom of a New York-bound Greyhound bus. (Source: The Boston Herald, February 5, 2001)

- January 30, 2001: Gunmen fleeing a robbery in Hillsdale, Missouri fired at least one shot at a moving bus, injuring a passenger aboard the bus. (Source: St. Louis Post-Dispatch, January 31, 2001)

- January 29, 2001: Passengers ducked for cover aboard a Pierce Transit bus in Tacoma, Washington, when gunfire aimed at the vehicle punched a nickel-sized hole in two ventilation windows some 18 inches above the seated passengers. (Source: Seattle Post-Intelligencer, January 30, 2001)

- January 24, 2001: Gang members shot at a group of rivals who were riding in a Durham Area Transit Authority bus in Durham, North Carolina, injuring a teenage girl and causing the bus driver to speed away with more than 20 passengers aboard. At least five bullets penetrated a side window of the bus. (Source: The News and Observer, January 26, 2001) 
- January 13, 2001: A woman stabbed a SEPTA bus driver, Garfield Gilbert, in Delaware County, Pennsylvania after making fun of his Jamaican accent and making ethnic slurs. (Source: The Associated Press State and Local Wire, January 15, 2001)

- January 5, 2001: Commuter rail service was suspended for two hours at Waverly Station in Belmont, Massachusetts while bomb squad officers investigated a bomb threat. (Source: The Boston Globe, January 6, 2001)

- January 4, 2001: A bus passenger brutally beat a Metro Transit driver, Ismael Ayoub, and drug him off the bus in Minneapolis, Minnesota, after becoming angry at having to wait for police to help Ayoub deal with some women who had refused to pay their fares and refused to get off the bus. (Source: Star Tribune, January 22, 2001)

- December 20, 2000: A 29-year-old man hijacked a Metropolitan Area Transit bus in Council Bluffs, Nebraska, ordered the bus driver to drive "expeditiously" to Omaha and assaulted and threatened to kill a female passenger on board the bus. (Source: Omaha World-Herald, December $23,2000)$

\section{Major Violent Attacks on Mass Transportation in the US}

- $\quad$ August 6, 1927: Two bombs explode in two New York City subway stations, one in the 28th St IRT (Lex Line) station and the 28th St (B'way) BMT station. "[The bombs] injured many persons, one of them it was believed, fatally." (NYT 8/6/1927)

- December 7, 1993: Armed gunman, Colin Ferguson, kills 6 and injures 17 passengers aboard a Long Island Railroad train during rush hour.

- December 15 and 21, 1994: Edward Leary explodes two homemade bombs on the New York City subway system, injuring 53 people, in an apparent attempt to extort money from the New York Transit Authority.

- October 9, 1995: "Sons of the Gestapo" sabotage Amtrak’s Sunset Limited train, causing a derailment in the Arizona desert, killing one and injuring 65 others.

- November 27, 1998: A deranged passenger on a Seattle Metro bus shot and killed bus operator and ATU Local 587 member Mark McLaughlin, causing the bus to careen off a bridge and resulting in the death of one passenger and injuring 32 others.

Source: http://atu.org/TransitTerror.htm 


\section{STATE OF FLORIDA ANTI-TERRORISM INITIATIVES}

\section{Governor's Office}

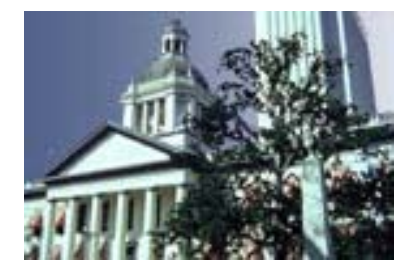

On September 14, Governor Jeb Bush directed the Florida Department of Law Enforcement (FDLE) and the Division of Emergency Management (DEM) to immediately complete a comprehensive assessment of Florida's capability to prevent, mitigate, and respond to a terrorist attack. Under the state plan, FDLE is the lead agency for crisis management and DEM is the lead agency for consequence management. The Governor directed these agencies to consult with all involved parties and recommend improvements for strengthening the state's antiterrorism strategy within ten working days. Governor Bush further directed that the assessment examine the State's capabilities regarding training programs, equipment, and execution protocols, focusing particularly on preventing/mitigating a terrorist attack.

To meet these goals four primary workgroups were formed around the State's existing emergency support functions: Emergency Services, Human Services, Critical Infrastructure, and Public Information \& Awareness. Using the existing networks of law enforcement, firefighters, emergency medical services, and selected private sector partners, these workgroups collected information about Florida's existing capabilities and capacities.

An assessment tool was developed and deployed to collect critical information not already available at the State level. Outstanding response was received from sheriffs, police, fire/Rescue, emergency medical, and State agencies, as well as critical private sector industries. Although this was not a scientific survey, the returned instruments provided valuable insight into the status of Florida's anti-terrorism preparedness. Subject matter experts were asked to join the workgroups to review and analyze the information and develop recommendations for strengthening Florida's safety and security framework. Recommendations of this group were reviewed, validated and approved by the chief executives of State, County, and Municipal agencies with emergency responsibilities in Florida.

The primary recommendations for strengthening Florida's anti-terrorism preparedness are outlined in the Task Force Report: Assessing Florida's Anti-Terrorism Capabilities, September 2001. This report can be viewed at http://www.fdle.state.fl.us/publications/anti-terrorism.pdf

On October 11, 2001, Governor Jeb Bush signed Executive Order \#01-300, (http://www.dca.state.fl.us/fdem/executive order_01_300.pdf) strengthening the state's capacity to enhance domestic security and to combat terrorist activities. The order directs state agencies to implement safeguards to enhance protection of all Floridians.

The following actions are to be taken immediately, or upon legislative approval of funding if necessary:

\section{Law Enforcement Initiatives (Florida Department of Law Enforcement):}

- Creates seven Regional Domestic Security Task Forces, under the auspices of FDLE, to coordinate responses to terrorist incidents, ensure proper training for state and local personnel, and collect and disseminate terrorist intelligence;

- Begins the process of training local law enforcement, fire, emergency and other "first responders;"

- Calls on FDLE to make recommendations on funding, prioritizing and distributing equipment for emergency personnel to safely perform anti-terrorism duties;

- Creates a statewide anti-terrorism database for use by all Florida law enforcement agencies; and

- Reiterates the importance of aggressively combating hate crimes against ethnic groups in coordination with Florida's Attorney General and local law enforcement.

- $\quad$ Chemical and Biological Attack Initiatives (Department of Health (DOH)):

- Directs DOH to take steps to ensure quick dissemination of medical information about chemical and biological attacks;

- Directs stockpiling of necessary pharmaceutical treatments for potential attacks;

- Creates a fully-staffed statewide epidemic intelligence service; and

- Directs the implementation of a training program for health officials across the state. 


\section{Driver's License Initiatives (Department of Highway Safety and Motor Vehicles (DHSMV):}

- Provides for electronic sharing of driver's license information with FDLE and other criminal justice agencies;

- Allows issuing 30-day temporary permits when time is needed by the DHSMV to verify an applicant's identity;

- Limits the duration of driver's license to the duration of INS documents; and

- Directs DHSMV to retain electronic copies of any foreign document used to establish identity.

\section{Specialized Anti-Terrorism Personnel:}

- Allows the Commissioner of FDLE to serve as, or name a, Chief of Florida Domestic Security Initiatives, and directs FDLE to report to the Governor and legislative leadership by November 1, 2001 , on additional efforts needed to combat terrorism; and

- Creates an 11-person Florida Domestic Security Advisory Panel to provide and evaluate recommendations for combating terrorism.

\section{Department of Community Affairs (DCA) - Division of Emergency Management (DEM)}

See the bureau web site at http://www.floridadisaster.org/.

The Division of Emergency Management, within the Department of Community Affairs, ensures that Florida is ready to handle any emergencies, recover quickly from them, and mitigate against their adverse impact. The DEM administers the State's Comprehensive Emergency Management Plan (CEMP), which establishes the framework to ensure that the State of Florida will be adequately prepared to deal with the variety of hazards that threaten our communities, businesses and environment.

The Division contains the following bureaus:

Compliance Planning \& Support

The Bureau of Compliance Planning and Support reviews site plans to enhance first-response efforts at facilities storing hazardous materials, and assists facilities with reporting requirements and compliance verification. Staff also conduct on-site audits of county CEMPs and provide technical assistance for plan development. The bureau also administers the Emergency Management Preparedness and Assistance Trust Fund, county base grants, and incoming federal, state, or private funding through the Finance and Logistics Management Section. This section also works directly with the Bureau of Preparedness and Response to assist with the logistics of disaster response and recovery operations and with all branches of state government to ensure resources are managed efficiently.

\section{Policy \& Planning}

The Office of Policy and Planning section is primarily responsible for formulating policy for the Division involving all emergency management issues. They are also responsible for developing the division's areas of the Agency Strategic Plan, the Five-Year Strategic Plan, and the State Land Plan. The office develops Executive Orders to engage state resources in disasters, prepares Presidential Disaster Declarations or Emergency Requests, Small Business Administration disaster declaration requests, and others. This office coordinates administration of the U.S. Department of Justice's mass immigration plan.

\section{Preparedness \& Response}

The Bureau of Preparedness \& Response is responsible for developing and maintaining the State's ability to effectively respond to a wide variety of threats. The Bureau has two Sections: Preparedness and Response, and two independent support units: the Technical Support Unit, and the Administrative Support Unit.

\section{$\underline{\text { Recovery \& Mitigation }}$}

The Bureau of Recovery and Mitigation works to reduce or eliminate long-term risk to human life and property from disasters. Assistance for recovery from disasters is provided through the federal infrastructure assistance, human services assistance, and the Hazard Mitigation Grant Program. These programs help to rebuild lives and communities that have been impacted by a major disaster, and to reduce the impact of future disasters through mitigation.

The following DEM resources specifically address terrorism. 
Comprehensive Emergency Management Plan Annex B - Terrorism Response Plan. This document is one of several hazard specific annexes to the State of Florida Comprehensive Emergency Management Plan. It defines the State's program to prepare for and respond to such a terrorist or cyber terrorist event. Annex B (the Terrorist Incident Response Plan) establishes the policies, programs, and procedures that will be utilized by State agencies and organizations to prepare for, respond to, and recover from a threatened or actual emergency resulting from a terrorist act. It also defines the roles of local and federal government agencies in the development, implementation, and maintenance of the statewide system.

http://www.dca.state.fl.us/fdem/annexb terrorism.htm

Sample: Local Terrorism Incident Response Annex To a County or City Comprehensive Emergency Management Plan. This sample plan can be utilized as a basis and developmental tool for all counties and municipalities in the State of Florida to formulate their own agency-specific Terrorism Response Annex. http://www.dca.state.fl.us/fdem

Terrorism Web Site. Site dedicated to terrorism, how should Florida prepare for terrorism, what to do before, during, and after a terrorist incident, what the community can do, actions to take to prepare, and where to get more information on bioterrorism, anthrax, guidelines for suspicious packages, federal emergency management agency, American Red Cross, National Domestic Preparedness Office, FDEM Terrorism information, and the FDLE Anti-terrorism capabilities report. http://www.floridadisaster.org/bpr/EMTOOLS/Severe/terrorism.htm

\section{Terrorism Summit}

The State of Florida 1999 Terrorism Summit was provided under the authority and funding of the State of Florida, Department of Community Affairs, Division of Emergency Management (DEM) through a grant from the Federal Emergency Management Agency (FEMA). The summit activities built upon the knowledge and experiences of the summit participants.

DEM hosted the Summit on July 27-29, 1999 in Orlando to seek the guidance of numerous "experts," representing a variety of functional disciplines for the development of a draft statewide terrorism strategy. The summit emphasized coordination, integration of capabilities (local, state, and federal), problem identification and resolution, identification of needs, and identification of sources of programs and funding to aid in the development of local and statewide terrorism strategies. The Summit's objectives included:

- Identification of current and proposed federal and state terrorism programs and sources of funding.

- Participant involvement in continuing the development of a draft state terrorism strategy.

- Incorporation of identified strategy components towards the development of a needs assessment.

- Identification of members to serve on a State Working Group for Domestic Preparedness.

Resources produced from the Summit's include:

1999 Terrorism Summit Manual. This manual was developed to address the Summit's objectives and includes materials necessary to draft a statewide terrorism strategy.

http://www.dca.state.fl.us/fdem/bpr/EMTOOLS/Terrorism/Summit/index.htm

State of Florida 1999 Terrorism Summit After-Action Report. This After-Action Report (AAR) was produced with the help, advice, and assistance of the State of Florida 1999 Terrorism Summit participants from many local and state agencies and departments. The purpose of publishing this AAR was to document the process that took place for developing the draft statewide terrorism strategy. It serves as a compendium of lessons learned, outlines necessary future actions, and provides the basis for planning future terrorism policies and procedures.

http://www.dca.state.fl.us/fdem/bpr/EMTOOLS/Terrorism/Summit/A-AAR.html 


\section{RESOURCE DOCUMENTS}

The following are resources to assist transit agencies in developing or enhancing security plans and procedures. When available, the full text of these documents can be found at the Internet address provided.

\section{From Volpe National Transportation Systems Center: http://www.volpe.dot.gov/}

Title:

Author(s):

Year:

Perspectives on Transit Security in the 1990s: Strategies for Success

Administration: Federal Transit Administration (FTA)

Keywords:

Local transit-Security measures

Volpe Report \#: $\quad$ DOT-VNTSC-FTA-96-02

DOT Number: $\quad$ FTA-MA-90-7006-96-01

NTIS Number: PB96-185871

Title:

Author(s):

Year:

Transit Security: A Description of Problems and Countermeasures

Mauri, Ronald A.; Cooney, Nancy A.; Prowe, Garry J.

1984

Keywords:

Volpe Report \#:

Urban Mass Transportation Administration (UMTA)

DOT Number:

Local transit crime--Prevention; Local transit--Security measures

DOT-TSC-UMTA-84-22

UMTA-MA-06-0152-84-2

Title:

Author(s):

Year:

Transit Security Handbook

Administration: Federal Transit Administration (FTA)

Keywords: $\quad$ Local transit-Security measures

Volpe Report \#: $\quad$ DOT-VNTSC-FTA-98-03

DOT Number: $\quad$ FTA-MA-90-9007-98-1

NTIS Number: $\quad$ PB98-157761

URL:

http://transit-safety.volpe.dot.gov/publications/Security/TransitSecurityHandbook.pdf

The handbook provides both oversight agency and RFGS personnel with an overview of the rail security function, including: the development of a State Security Oversight Program; the establishment of a rail transit police or security department; the development of a system security program plan (Security Plan); the deployment of uniformed and plainclothes police and security personnel; crime prevention through environmental design (CPTED) and situation crime prevention (SCP) techniques for rail facility design and operation; the use and management of security technology; and techniques for crime data collection and analysis. Finally, the handbook contains information that will support the efforts of rail transit agencies to comply with the requirements specified in Part 659.

Title:

Author(s):

Year:

Transit Security Procedures Guide

Administration: Bureau of Transportation Statistics (FTA)

Keywords: $\quad$ Local transit-Security measures

Volpe Report \#: $\quad$ DOT-VNTSC-FTA-94-08

DOT Number: $\quad$ FTA-MA-90-7001-94-2 
This guide is designed to help transit systems become aware of the procedures used across the country by transit and other programs in their security tasks. The guide includes information on how to apply the systems approach to transit security planning and implementation; proactive materials on the prevention of security incidents; procedures for immediate and follow-up response to security incidents; and specific evaluations of a variety of special security problems including crimes against passengers, crimes against the transit system, crimes against the public (hostages, hijacking, bomb threats), and general security issues. This is a companion to an earlier document entitled "Transit System Security Program Planning Guide" also available from Volpe and FTA.

Title:

Author(s):

Year:

Transit Security in the 90's Powell, Kathryn C.

Administration: Federal Transit Administration (FTA)

Keywords:

Volpe Report \#:

DOT Number:

Local transit-Security measures

NTIS Number:

FTA-MA-26-9009-97-01

PB97-146989

As a result of the Federal Transit Administration's concern for the potential of terrorist attacks on our Nation's transit systems, especially in a year when we are hosting the Olympics, a conference was held in Atlanta, Georgia, on February 27-28, 1996. The purpose of this conference was to assist transit security specialists to recognize, prepare for, and respond to the terrorist threat. This document summarizes the proceedings of the conference.

Title:

Author(s):

Year:

Transit System Security Program Planning Guide

Administration: Federal Transit Administration (FTA)

Keywords: $\quad$ Local transit-Security measures

Volpe Report \#: DOT-VNTSC-FTA-94-01

DOT Number: $\quad$ FTA-MA-90-7001-94-1

NTIS Number: $\quad$ PB94-161973

The guide discusses each aspect of a security plan to ensure that when complete, the plan document will demonstrate management's commitment and policy regarding security; introduce the concept of a System Security Program; describe the transit system; establish the management of the plan; detail the security program by assigning responsibilities; explain how threats and vulnerabilities will be identified, assessed, and resolved; describe how the plan itself will be implemented to establish or revise the program; and describe how the security plan will be evaluated and modified. Additional information in the appendixes will make the complete security plan a valuable security reference. The guide includes a transit security bibliography of approximately 200 documents.

\section{From Mineta Transportation Institute http://www.transweb.sjsu.edu/transweb.htm}

Protecting Surface Transportation Systems and Patrons from Terrorist Activities, Brian Michael Jenkins, January 1997 (Out of print)

Full text available at: http://www.transweb.sjsu.edu/publications/terrorism/Protect.htm

Contemporary terrorists have made public transportation a new theater of operations. For those determined to kill in quantity and willing to kill indiscriminately, public transportation offers an attractive target. Because it is public and used by millions of people daily, there is necessarily little security. Passengers are strangers, promising attackers anonymity. Concentrations of people in contained environments are especially vulnerable to conventional explosives and unconventional weapons and attacks on public transportation, the circulatory systems of urban environments, cause great disruption and alarm, which are the traditional goals of terrorism.

In order to effectively meet the threat posed by terrorism and other forms of violent crime, it is essential that transportation system operators have a thorough understanding of the security measures employed elsewhere, especially by those transportation entities that have suffered terrorist attacks or that confront high threat levels. 
This volume reports on the first phase of a continuing research effort carried out by the Norman Y. Mineta International Institute for Surface Transportation Policy Studies (IISTPS) on behalf of the U.S. Department of Transportation. It comprises a chronology of attacks on surface transportation systems; four case studies of transportation security measures (in Paris, Atlanta, and New York, and at Amtrak); security surveys of nine additional cities in the United States; and an annotated bibliography of current literature on the topic.

Protecting Surface Transportation Systems Against Terrorism and Serious Crime. Brian Michael Jenkins, October 2001 (Available October, 2001)

Contemporary terrorists have made public transportation a new theater of operations. In order to effectively meet the threat posed by terrorism and other forms of violent crime, it is essential that transportation system operators have a thorough understanding of the security measures employed by other operators, and especially by those entities that suffered terrorist attacks or confront a high level of threat.

In a previous Institute project, four case studies were completed (New York, Atlanta, Paris, and Amtrak). The results from this research were combined with the results of a Federal Transportation Agency survey of nine public transportation systems in the United States. The results of the previous study were published by IISTPS as Protecting Surface Transportation Systems and Patrons from Terrorist Activities, (IISTPS Report 97-4).

This project will address:

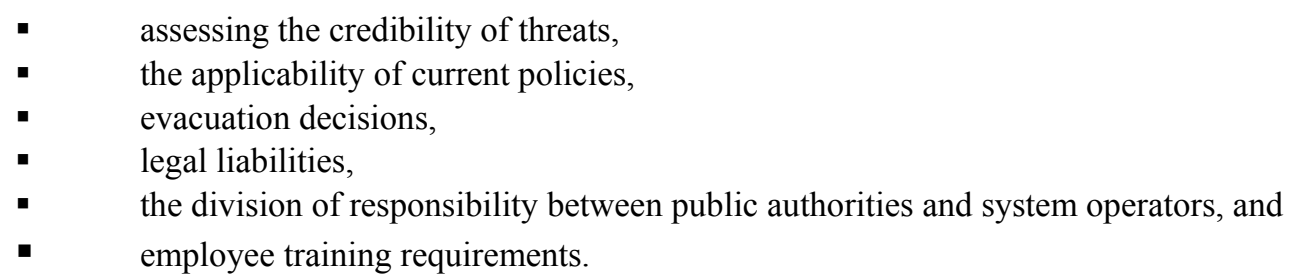

\section{Terrorism in Surface Transportation - A Symposium. Published March 1996}

The topic for this symposium was selected to help satisfy the increased need for awareness of and preparedness for possible terrorism attacks on the surface transportation systems within the United States and the world. A group of experts was assembled to present a summary of their vast experience and concerns in the areas of terrorism to an invited group of delegates drawn from transportation agencies, law enforcement, other government agencies and the private sector. Interactive discussions and panels were also held. The speakers included representatives from the New York Transit Authority, the Federal Bureau of Investigations, Amtrak, and American Medical Response West. Topics included lessons learned from the Oklahoma City Bombing, the World Trade Center Bombing, the Unabomber, and the Arizona Derailment. Emergency medical responses were also discussed.

Source: San Jose University, Mineta International Institute for Surface Transportation Policy Studies

\section{Transit Cooperative Research Program Reports}

\section{Improving Transit Security. Jerome A. Needle and Renee M. Cobb, J.D, 1997.}

Many transit agencies are experiencing an upsurge in both the incidence and intensity of violence in and around its vehicles and stations. The costs - financial and social --associated with those violent incidents is tremendous. They involve escalating worker's compensation payments and medical expenses; higher levels of assault pay; increased absenteeism and worker anxiety; deterioration of equipment and increased frequency of required repair; decreased ridership, and greater passenger fear for personal safety. A number of issues should be addressed when developing a program to combat an increase in violence, including coordination of efforts with local law enforcement, schools, and community groups. There is also a need for considering engineering and design changes to provide greater structural safety to vehicle operators, station agents, and patrons. This synthesis describes good practices in conflict avoidance.

Source: TCRP Synthesis 21, Transportation Research Board, National Research Council. Web site: http://nationalacademies.org/trb/publications/tcrp/tsyn21.pdf 
Emergency Preparedness for Transit Terrorism. Annabelle Boyd and John P. Sullivan, 1997.

The threat of terrorism in various forms has been directed in increasing frequency toward bus and rail public transit organizations. Some transit agencies have extensive emergency procedures available for handling fires, accidents, power outages, and so forth; however, there are aspects of potential terrorist acts with which transit systems, and the municipalities and communities in which transit agencies operate, may be ill prepared to deal. Of particular concern is the ability, or lack thereof, of municipalities, transit agencies or other governmental agencies engaged in emergency response or crisis management to detect, classify, and properly react to a range of threats, including chemical, biological, and explosive devices. Key issues such as the following are covered: Internal organization emergency responsibilities; detection, classification, and response procedures; crime prevention through environmental design (CPTED); coordination with first responders to include memoranda of understanding; training for employees and other emergency and responding agencies; interagency training and drills; coordination with other responders, such as state and federal agencies; command and control systems, including communications; and identification of funding sources for technology, training, and research.

Source: TCRP Synthesis 27, Transportation Research Board, National Research Council.

Web site: http://nationalacademies.org/trb/publications/tcrp/tsyn27.pdf

\section{TR News}

\section{Preparing for Transit Terrorism.}

The contents of this periodical include: Traffic Estimation and Prediction System; Transportation-Related Noise in the United States; Emergency Preparedness for Transit Terrorism; Annual Meeting Highlights; Research Pays Off: Fiber-Reinforced Polymer Composites for Strengthening Bridges in Oregon; Profiles; News Briefs; TRB Highlights: CRP News; Calendar; and Bookshelf: TRB Publications.

Source: TR News, May-June 2000, Number 208

Web site: http://nationalacademies.org/trb/publications/trnews/trnews208.pdf - for cover and table of contents.

\section{Transportation Security: Protecting the System from Attack and Theft.}

Articles from this issue include:

\section{Transportation Security: Agenda for the 21st Century}

Stephen E. Flynn

Criminals plan to exploit and terrorists plot to disrupt the U.S. transportation system. Because both activities are escalating, transportation security must become a national priority, according to this author. The solution requires global initiatives that complement concerns about cost and competitiveness.

\section{Information Systems Security: The Federal Aviation Administration's Layered Approach \\ Daniel J. Mehan}

FAA is establishing a security system reinforced at every level, ensuring the safety of U.S. airspace and airports and protecting one of the world's largest and most complex information-centric critical infrastructures.

\section{Cargo Security: High-Tech Protection, High-Tech Threats}

\section{Ed Badolato}

Computer-savvy criminals, backed by syndicates and assisted by corporation insiders, are manipulating the new shipping technology for illicit gains. Security professionals must maintain the expertise to anticipate and prevent sophisticated theft at every link in the worldwide supply chain.

\section{U.S. Military Preparedness: Jammed in the Traffic?}

Bob Honea

The economic boom has the U.S. transportation system operating near capacity. Can commercial activities afford to make room for military transportation in a national emergency? A panel of military and civilian experts presented insights at two TRB conferences. 


\section{Statewide Critical Infrastructure Protection: New Mexico's Model}

Daniel J. O’Neil

Programs to protect statewide, regional, and local infrastructure are necessary to complement—and adapt—federal initiatives. New Mexico provides a pioneering example.

\section{Improving Surface Transportation Security Through Research and Development}

Daniel F. Morgan and H. Norman Abramson

The federal government must set priorities for research and development to secure the surface transportation system, avoiding duplication of effort, coordinating findings among agencies, and implementing and assessing improvements, according to a National Research Council study.

\section{National Maritime Policy: Reforms Should Boost Trade, Relieve Landside Congestion}

\section{A. J. Herberger}

The United States must reform its patchwork maritime policy to enhance industry competitiveness in global markets, a retired vice admiral advises. Reforms also should encourage development of coastal routes to relieve highway traffic and introduce travel and shipping alternatives.

Source: November-December 2000, Number 211

Web site: http://www.nas.edu/trb/publications/trnews/trnews211.pdf

\section{Other Resource Documents}

Public Transit Reacts to Horrific Terrorist Attacks.

With the deadly terrorist attacks on the World Trade Center and the Pentagon on September 11, the nation's public transportation community has had much the same reaction as the general population: shock, anger, sadness, and an overwhelming, immediate desire to help. This article from Passenger Transport, that can also be found in full-text on the APTA website, discusses the reaction of public transit in regard to several different transportation agencies in New York, Washington, nationally, and internationally.

Source: Passenger Transport, September 17, 2001 (Vol. 59, No. 37)

This article can as be found on the web at: http://www.apta.com/news/pt/0917-response.htm

\section{Practical Security and Emergency Response Advice From New York and Washington, D.C.}

The Federal Transit Administration (FTA) has compiled a "lessons learned" from providers of public transportation in the New York and Washington D.C. metropolitan areas since the devastation of September 11th. A summary of the recommendations is available.

Web site: http://www.fta.dot.gov/office/public/c1201/attacha.html

Mass Transit: Target of Terror. Kurt P. Nelson, 1999.

Few local law enforcement agencies are prepared to combat acts of terrorism, and mass transit systems remain particularly vulnerable. This article discusses how in recent years, both domestic and foreign terrorists have been increasingly focused on mass transit. It concentrates on the following topics: preparing for terrorism; defining the terrorist threat; transit system considerations; and prevention strategies.

Source: FBI Law Enforcement Bulletin Vol. 68, No. 1 (Jan. 1999). Pages 19-24

Web site: http://www.fbi.gov/publications/leb/1999/jan99leb.pdf

Defending Subways Against Biological Terrorism. David Siegrist and Peter Lejeune, 1998.

Transit police may find themselves on the front lines of America's strategic challenge for the 21 st century, homeland defense. It is through the underground transport system that a terrorist or rogue nation may find the easiest means to attack the cities of the United States. Field experiments conducted by the US Army in the 1960s using the harmless bacillus globigii stimulant showed that much of New York City could have been infected by an attack on the subway system, with the agent being disseminated through ventilation shafts and station openings. This article discusses this case and its findings on prevention.

Source: Transit Policing Vol. 8, No. 2 (Fall 1998). Pages 7-10.

Web site: http://www.potomacinstitute.org/press/transitpolicing.htm 
Technology and Transit Terrorism: Trends and Possibilities. Robert J. Bunker, 1997.

Transit terrorism has gained heightened attention from the transit police service due to the increased frequency of both threats and actual incidents, which are also growing in severity. This article looks at how terrorism is changing, the specific transit facility/system target sets that can be attacked, and the current technology employed in transit terrorism. Based on this analysis, projections concerning trends and possibilities of technology employment in transit terrorism are made.

Source: Transit Policing Vol.7, No. 1 (Spring 1997). Pages 14-23.

Location: This article can be found at the Transportation Library in the Northwestern University Library.

\section{Chemical Terrorism Response in Public Facilities. Susanna P. Gordon, 2000.}

The trends of terrorism towards large-scale, high-visibility, high-casualty assaults and towards attacks on public transportation facilities support the rising concern about chemical attacks on public facilities. The incidence of the Tokyo subway being attacked by Aum Shinrikyo in 1995 that resulted in the death of 12 people, caused 5500 casualties, and impacted 15 subway stations is discussed in this article. This article also informs how a wellprepared facility emergency response system can significantly reduce the impacts of a chemical attack and may discourage such attacks from taking place.

Source: Transit Policing Vol. 10, No. 1 (Spring 2000). Pages 5-10.

Location: This article can be found at the Transportation Library in the Northwestern University Library.

Cops, Cameras, and Enclosures: A Synthesis of the Effectiveness of Methods to Provide Enhanced Security for Bus Operators. National Center for Transit Research, Center for Urban Transportation Research, 2001.

The safety of operators and passengers is a primary concern of transit systems and has become an increasingly important issue to transit bus operators themselves. A number of transit agencies use different techniques to minimize the possibilities of assaults against bus operators and passengers such as uniformed or plainclothes police officers or security guards, digital cameras, and/or bus operator enclosures. This research surveyed transit agencies that have used these techniques to determine their level of success, cost effectiveness, and acceptance by both bus operators and passengers. The study also identifies other techniques used to ensure the safety of bus operators such as passenger relations training to avoid conflict. The effect of "full wrap advertising" on passenger safety is also explored. The findings are presented in synthesis form.

Web site: http://www.nctr.usf.edu

Improving Surface Transportation Security: A Research and Development Strategy. Transportation Research Board and National Research Council, 1999.

The surface transportation system is vital to our nation's economy, defense, and quality of life. Because threats against the system have hitherto been perceived as minor, little attention has been paid to its security. But the world is changing, as highlighted by dramatic incidents such as the terrorist chemical attack on the Tokyo subway in 1995. Research and development can contribute to that response in important ways.

The first step is to develop a better understanding of the problem. The U.S. Department of Transportation (USDOT) has already begun this effort by assessing the surface transportation system's vulnerability to hostile attacks. Further work is needed in some areas, particularly regarding chemical, biological, and cyber attacks, and especially the strategic vulnerability of the surface transportation system as a whole that may result from internal and external interdependencies.

USDOT's first priority in setting up a research and development program for the security of surface transportation should be to define and put in place a clear and comprehensive strategy. That strategy should be founded on a systematic process of five steps: clear definition of the problem and objectives, identification of a wide variety of possible solutions, rigorous evaluation of those alternatives, careful decision making, and effective implementation.

First, a dual-use approach, in which security objectives are furthered at the same time as other transportation goals, can encourage the implementation of security technologies and processes. Second, modeling could be used to develop a better understanding of the scope of the security problem. Third, USDOT can play an important role in 
developing and disseminating information about best practices that use existing technologies and processes, including low-technology alternatives. Finally, security should be considered as part of a broader picture, not a wholly new and different problem but one that is similar and closely connected to the transportation community's previous experience in responding to accidents, natural disasters, and hazardous materials.

Web site: http://books.nap.edu/html/improv_surf_transp/

Control of Public Space. Peter Whent, May 1999.

Presents a safety and security strategy as utilized throughout the railway networks of England, Scotland, and Wales, including the London Underground.

Source: APTA 1999 Rapid Transit Conference Proceedings Paper.

Web site: http://www.apta.com/info/online/whent.pdf

Transport Safety, Public Safety And Public Transport: Exploring An Intricate Relationship. E. de Boer, 1999.

This paper describes factors impacting public safety in public transportation as related to traffic safety. These issues have been investigated for the Dutch high-speed eastern railway line. Subjects explored include transportation of hazardous materials, terrorism, the use of tunnels in railroad infrastructure, and public perception of safety in railway stations and tunnels.

Source: Second World Congress on Safety of Transportation: Imbalance between Growth and Safety Conference Proceedings.

Available from: Delft University Press, Postbus 98, 2600 MG Delft, Netherlands

Transit Passenger Perceptions Regarding Transit-Related Crime Reduction Measures. Thomas B. Reed, Richard R. Wallace, Daniel A. Rodriguez, November 19, 1999.

Violent crimes against public transit bus operators and passengers in Michigan were studied. The study was funded by the Michigan Department of Transportation and conducted by the University of Michigan in early 1999. A survey approach examined transit passenger perceptions of numerous transit-related crime reduction measures, primarily patrol and security, design actions, and technological innovation. The respondents ranked emergency telephones for passengers and increased lighting as the best crime prevention measures. The survey was part of a wider study that also surveyed transit agencies and transit vehicle operators.

Source: Transportation Research Record - Journal of the Transportation Research Board 173

Available from: $\mathrm{http}: / /$ nationalacademies.org/trb/bookstore/ 


\section{TRANSIT SECURITY TRAINING AND SEMINARS}

\section{TSSI, Inc.}

Total Security Services International, Inc. offers counter-terrorism training for transit personnel. For more information on their seminar offerings contact TSSI at telephone (770) 509-8800, email tssi1@msn.com, or visit their website www.totalsecurityservices.com.

\section{TSI}

Transportation Safety Institute (TSI) conducts seminars on safety around the country. Information on their courses and seminars can be obtain on their website http://www.tsi.dot.gov or by contacting Jim Lopez, manager of TSI's Transit Safety and Security Division, at (405) 954-3682.

\section{Selected courses:}

Transit System Security. Participants will receive the knowledge and tools to develop a system security program plan and implement the program. They will learn to use resources to reduce crime and improve passenger and employee security. This course provides participants with a uniform format for developing and implementing security policies and procedures through a system security program plan with crime prevention as the major component. Included are basic security terms, the five steps in threat and vulnerability identification, and the resolution process. The course addresses security in system planning, design and construction; agency policies and procedures; managing special security issues; and various types of transit security staffing. In the event of a critical incident, the system security program plan provides for mobilization of transit and other public safety resources to assure a rapid, controlled, and predictable response and resolution.

Objectives: System security program plan and state safety oversight; Developing a system security program plan; Security responsibility, policies and procedures, proactive security activities; Threat and vulnerability analysis, pre-incident indicators; Security by design, crime prevention through environmental design; Proactive procurement; Establishment of a security force; Bomb threat incidents and terrorist acts; Chemical, biological, and nuclear threat awareness; Vandalism, gang activity, fare evasion, and workplace violence; Managing the media; Crime prevention and problem oriented policing; Common security audit deficiencies; Group exercises, site review, quizzes and exam; Group exercise: security assessment.

Transit Explosives Incident Management Seminar. This seminar demonstrates how to prepare for and initially respond to acts of terrorism, implement a plan and procedures to respond to an explosive incident, and manage an incident and the media. Participants are trained in general security awareness in the transit environment, how to identify flaws in facility or vehicle design, and how to discourage criminal activity. Two seminars are usually conducted at the host site; PM on the first day and AM on the next day to encourage agency participation.

Objectives. Identification of vulnerability, potential threats to transit systems, terrorist tactics; Identification of explosive components; How to search for explosives and secondary devices; Development and review of explosives incident plans and evacuation procedures; Media relations; Presentations from local police department bomb technicians

Response to Weapons of Mass Destruction. This course provides information on historical chemical/biological/nuclear terrorist incidents, current events, the nature of chemical/biological/radiological agents, and how to respond to such events in a transit environment. Internal and external resources, transit's role in responding to community incidents, and the roles and crossjurisdictional responsibilities of emergency responders are identified.

Objectives. Introduction to transit terrorism; Characteristics of response to terrorist incidents; Characteristics of chemical, biological, radiological agents; First responder considerations; Elements of response to a $\mathrm{CBN}$ incident: detection, responder protection, scene control, and notification; Planning for a CBN incident response; Managing the incident; Roundtable discussion; Tabletop simulation exercise based on host property's environment and concerns. 
Threat Management and Emergency Response to Rail (Train) Hijackings Seminar. Participants will be taught how best to respond to acts of terrorism, including workplace violence, and how to develop and implement a plan and procedure to respond to hijackings. They will learn how to gain access to the rail vehicle and resolve the incident with minimal public endangerment. Two seminars are usually conducted at the host site due to participation of emergency responders.

Objectives. Introduction to terrorism, tactics; Bombs, chemical/biological/radiological incident history, and emergency management planning; Identification of flaws in facility design and operation; Developing an emergency response plan; Rail car accessibility (stopped, in motion); Planning a systematic response; Managing the media; Field exercise: preliminary safety briefing, simulation.

Effectively Managing Transit Emergencies. Participants learn how to develop and implement transit emergency management and response programs.

Objectives. Nature of emergencies and disasters; Emergency management concepts; Development of an emergency management plan; Incident command station and coordination of response efforts and resources; Emergency management training; Acquisition; Managing media relations; Tabletop simulations and group exercises, quizzes, exam.

\section{FLETC}

Information on the Land Transportation Anti-Terrorism Training Program can be accessed through the Federal Law Enforcement Training Center's website http://www.fletc.gov or by contacting the program specialist at (912) 2673186.

\section{NTI}

The National Transit Institute at Rutgers in New Jersey has awarded Tri-Met a contract to develop a comprehensive training program on how to prevent, respond to, manage, and recover from workplace violence incidents in the transit industry. Tri-Met will develop a resource guide on how to implement an effective workplace violence prevention program, as well as classroom training for front line employees, supervisors, and managers, and produce videos and a CD-ROM. Contact Adrian B. Moy at telephone (503)631-8341 or e-mail at adrianbmoy@home.com. 


\section{ADDITIONAL RESOURCE WEB SITES}

\section{Federal Departments/Agencies}

Federal Emergency Management Agency

www.fema.gov

FEMA: Rapid Response Information System www.rris.fema.gov

Federal Bureau of Investigation www.fbi.gov

National Domestic Preparedness Office www.fbi.gov/programs/ndpo/default.htm

Department of Health and Human Services www.hhs.gov

National Disaster Medical System www.ndms.dhhs.gov/index.html

Environmental Protection Agency www.epa.gov

Chemical Emergency Preparedness and Prevention www. epa.gov/swercepp/

Office of Emergency Response www.epa.gov/superfund/programs/er/index.htm

Department of Defense www.defense.mil

Department of Transportation www.dot.gov

Department of Energy www.doe.gov

U.S. Department of Agriculture www.usda.com

U.S. Army Soldier and Biological Chemical Command www.sbccom.apgea.army.mil

U.S. Army Medical R\&D Command http://mrmc-www.army.mil

U.S. Department of State Warnings http://travel.state.gov/travelwarnings.html

U.S. Department of Justice www.ojp.usdoj.gov

Medical (Army Surgeon General) www.nbc-med.org

Department of State (DOS) www.state.gov

DOS/Counterterrorism Coordinating Office www.state.gov/www/global/terrorism/index.html

Agency for Toxic Substances and Disaster Registry www.atsdr.cdc.gov/OFP/terrorism/indterr.html

Centers for Disease Control and Prevention www.cdc.gov

Disaster Management Central Resource http:/206.39.77.2/DMRC/dmrhome.html

Bureau of Alcohol, Tobacco, and Firearms www.atf.treas.gov

Chemical and Biological Defense Information and Analysis Center www.cbiac.apgea.army.mil 
U.S. Army Medical Research Institute of Chemical Defense http://chemdef.apgea.army.mil

U.S. Army Medical Research Institute for Infectious Diseases http://usamriid.apgea.army.mil

\section{Counter/Antiterrorism}

\section{U.S. Information Agency (USIA)} www.usia.gov/topical/po/terror/

Counterterrorism Page www.emergency.com/cntrterr.htm

National Terrorism Preparedness Institute http://terrorism.spjc.cc.fl.us

Terrorism Research Center www.terrorism.com

International Association Counterterrorism and Security Profession www.iacsp.com

Organization for the Prohibition of Chemical Weapons (OPCW) http://www.opcw.nl

Center for Nonproliferation Studies, Monterey Institute http://cns.miis.edu

The Stimson Center www.stimson.org/

The Joint Program Office for Biological Defense www.jpobd.net

The Defense Week Domestic Preparedness Site www.domesticpreparedness.com

Terrorism with $\mathrm{C} / \mathrm{B}$ Weapons www.cbaci.org/

Stockholm International Peace Research Institute (SIPRI) www.sipri.se/projects/chembio.html

Organizational Contacts

Florida Division of Emergency Management www.floridadisaster.org

American College of Emergency Physicians www.acep.org

National Association of EMS Physicians www.naemsp.org

International Association of Fire Chiefs www.iafc.org

International Association of Firefighters www.iaff.org

U.S. Fire Administration www.jusfa.fema.org

Emergency Net www.emergency.com/

Police Executive Research Forum www.policeforum.org

ECDIN - Searchable Chemical Database http://ulisse.etoit.eudra.org/Ecdin/E hinfo.html

Extension Toxicology Network $\underline{\text { http://ace.orst.edu/info/extoxnet }}$ 


\section{Chemical Weapons}

www.opcw.nl.ptshome.htm

Medical Web-Emergency

www.gen.emory.edu/medweb/medweb.html

National Research Council

www.nas.edu/nrc

National Sheriffs Association

www.sheriffs.org

SIRI MSDS Collection

http://hazard.com/msds

NBC Industry Group

www.nbcindustrygroup.com

International Association of Emergency Managers

www.emassociation.org

National Emergency Management Association (NEMA)

www.nemaweb.org 